\title{
Conceptual Art: The Untold Story of African Art
}

\author{
Osuanyi Quaicoo Essel, Ebenezer Kwabena Acquah \\ University of Education, Winneba, Winneba, Ghana
}

\begin{abstract}
Conceptual art is one of the twentieth century art movements that has gained popular attention in the contemporary artworld. It has received much scholarly prominence in the Western world, and perceived as an emergent art of European origin. What has been given little or no scholarly attention is the African essence of root of conceptual art movement. This article addresses the historical epochs of conceptual art in Africa and delves into the critical question of whether or not conceptual art is an emergent art in Africa. With the help of the images of African artworks, this article attempts to find visual answers by examining the art-historical account of the art through visual analysis in simple narrative format in telling the African side of the story. It concludes that the adoration and idolization of Marcel Duchamp as the father of conceptual art is contestable since the art was many centuries old in Africa before the twentieth century artists began to practice it in the West. Duchamp’s attempt at dematerialization of art, and showing distaste to the traditional aesthetics of Western art at the time through conceptual exploration had been in practice in African art and, therefore, not an invention.
\end{abstract}

Keywords: art, African art, art movements, conceptual art, contemporary art

\section{Introduction}

The artworld has sustained many art movements commonly referred to as "isms" of art. They include surrealism, dadaism, expressionism, cubism, impressionism, realism and abstractionism. These art movements came about as a result of the changing tastes for art consumption and continual increase in the questioning of the status quo in order to make creative contributions to the repertoire of art in general. The change in artistic tastes was formally determined by ethnic, regional, national and continental orientations towards the art. Differences in these artistic orientations was generally blurred by cultural shoulder-rubbing, education, trade, colonial domination, and the upsurge in technological inventions and innovations and its associated communicative gadgets which has made the entire world a global village. In the event, international dissemination of information and ideas about the creative happenings in the arts also increased in the twentieth century (O’Sullivan, 1998). The culturation process of the world has not totally wiped out the ethnic, regional, national and continental identities but rather encouraged artistic cultural borrowings amongst these entities.

Mass production of design aided by the use of the new technology in building and manufacturing became the order of the day. From the high quest for realism in the Renaissance period to the times of mass production of art objects in the twentieth century that characterized Western art traditions called for spicy artistic elements to 
reinvigorate their arts. Western artists at the time began to look outward and finally settled on African art from which they drew inspiration that sparkled the whole twentieth century art movements. The arbitrary use of colours, conceptual ideas and abstraction of the realia and socio-cultural events in artistic formats which has, hitherto, characterized the African art scene, and negatively labeled by the West as primitive, fetishistic, idolatrous, perverse, folk art (Nkrumah, 1963; Antubam, 1963; Dei-Anang, 1975; Amenuke, Dogbe, Asare, Ayiku, \& Baffoe, 1991) amongst others, became the lynchpin that stimulated their arts. One of the famous African Art historians, Kojo Fosu wrote that:

[The]... art of Africa was a factor that helped to save modern European artists from artistic decay and boredom. When Cubism and expressionist art were introduced to Europe for the first time, after centuries of their existence in Africa, it brought new vitality to European museums and galleries and also brought underserved economic gains to some European collectors and connoisseurs. (Fosu, 1975, p. 35)

Vansina (1984) adds that:

...wider recognition of African arts began in 1905 when European avant-garde artists in France and then in Germany recognized them as such. A wave of almost delirious enthusiasm followed and gave rise to the first private collections and to C. Einstein's Negerplastik (Leipzig, 1915), which set the tone for a spate of lyrical works that followed. Only artistic form mattered, social context and meaning were irrelevant! (p. 19)

Rubin (1984) wonders why it took about half a century before the publication of what he describes as a "the first comprehensive scholarly treatment” on the subject of African art influence on the West, though the influence had long been recognized in the works of the Western painters and sculptors (p. 4). In his contribution to the discourse on African art, Henry Moore outlines his inspiration from exhibits in the British Museum (British Museum Publications, 1981):

I was particularly interested in the African and Pacific sculptures and felt that "primitive" was a misleading description of them, suggesting crudeness and incompetence. It was obvious to me that these artists were not trying-and failing - to represent the human form naturalistically, but that they had definite traditions of their own. (p. 11)

Picasso also reacted to the magical force he sensed in the "Tribal Art" objects and regretted that "the Western tradition lost touch with the primordial sense of image-making as a magic operation” (Museum of Modern Art, 1985, p. 17). Until the late 1900s, cultural and geographic barriers provided Westerners limited opportunity to examine the perceptions of Africans about their artworks. To give their subjective impressions an ostensibly objective value, some scholars even assert universal standards of art criticism and good taste. Would their artistic impressions and judgments of African art be substantiated by the practitioners or people who used them?

Stuck to the old-fashioned traditional formalist way of analyzing artwork and being anew to African sculptural forms (Vogel, 1990), and coupled with the scanty written records on Africa’s art, led to the Westerners description of African art as "distortion to forms" (Nkrumah, 1964a, p. 65). They were not privy to Africa's conceptual and contextual hybridity of aesthetics that celebrate ideas expressed in her artworks. With no hindsight of this forethought imbed in African art, some of the Westerners who began to write on African art, took interest in studying European influence on African art and kept silent on how the art of Africa brought renewed interest in the twentieth century art. They also dwelled solely on its symbolic nature, everyday 
functionality, religio-magical and socio-political dimensions to make it appear inferior to Western art in a way to maintain the apparatus of colonial power (Nkrumah, 1963). But the reality is that pre-colonial African art attached no interest to the Western artistic canons-perspectival details, accurate proportions and representationalism. Instead, it created conceptual art that put the ideas expressed at its heart rather than the materials used. This objective truth about Africa's art was not articulated.

Conceptual art had lived with Africa for centuries though it was not named as such. This story in African art is untold, making some scholars to claim that conceptual art was Western invention, and labeling it as emergent art. Nkrumah (1964a) observes that:

Our history needs to be written as the history of our society, not as the story of European adventures... African ... history must be a mirror of that society, and the European contact must find its place in this history only as an African experience... (p. 63)

In consonance with Nkrumah's statement, we ask some pressing questions whose reflections could possibly lead to establishing this long awaited objective truth about conceptual art as an African phenomenon. In the context of African art history, was conceptual art a way of life? How does it permeate in the life of the African? Is it an emergent art to Africa? With the help of some images of African artworks found in museums, libraries, and anthropology textbooks, we attempt to find visual answers by examining this art-historical account through narrative inquiry and visual analysis in telling the African side of the story.

\section{What Constitutes “Art”?}

Art is a complex term to define. The philosophical concept of art has been debated over ages and there has not been any consensus on a definition of the word art. Its expansive nature inhibits an all-encompassing accurate definition. What is termed art in a particular time period tends to change as the discipline evolves over time. Fisher (1993) comments on the difficulty involved in formulating a common definition for art. To him, the nature of art allows all the actors in the art fraternity - the audience, curators, editors, critics, art historians, and theorists—play important role in determining the direction and definition of art. According to Abijian (2012), contemporary ${ }^{1}$ definitions of art are of two categories. One conventionalist definition emphasizes on institutional dimensions of art (as cited in Danto, 1981) that explains how art changes over time and the relational properties of artworks that hinge on the project's relations to art history, art genres and so on. A less conventionalist definition focuses on a wider and more traditional concept of aesthetic properties that includes art's pan-cultural and trans-historical characteristics.

Other definitions consider artworks as purposively endowed by their makers with perceptual properties of aesthetic interest; with a complicated history, new genres and art-forms evolve as a result of changing aesthetic experiences (Stanford Encyclopedia of Philosophy, 2012). There is institutional classification of the arts as found in natural entities such as landscapes, sunsets, flowers, and shadows and; abstract thoughts or theories considered as to possess aesthetic properties. However, Danto's institutional definition has the following necessary and sufficient conditions for something to be an artwork: if (a) it has a subject (b) about which it projects some attitude or point of view (has a style) (c) by means of rhetorical ellipsis (usually metaphorical) which ellipsis

\footnotetext{
${ }^{1}$ Contemporary_-It means current developments.
} 
engages audience participation in filling in what is missing, and (d) where the work in question and the interpretations thereof require an art historical context (as cited in Stanford Encyclopedia of Philosophy, 2012; Carroll, 2000; Danto, 1981).

Some definitions of art give advocacy to features that reflect the universality of art as in the cluster theories of art (Gaut, 2000; as cited in Davies, 2004; Carroll, 2002). These emphasize ten features of considering a work as an artwork. These include positive aesthetic features; expressing emotion, intellectually challenging; complex yet coherent; and complex in meaning. The rest are: relating to individual's perception; shows creative imagination; shows high sense of skill; part of an established artform; and a product of an artistic intention. However, some scholars prefer blurred or borderline definitions as against rigid compartmentalization (Stecker, 2005; Davies, 1991; Davies, 2006). But traditional definitions of art focus on a general single type of property: that feature could exhibit expressive, mimetic, representational, and formal properties. However, these definitions have some inherent issues. For example, having expressive, representational, and formal properties are not enough conditions for a concise definition.

Conceptual art has other dimensions rather than the physical attributes of the work. According to Lewitt (1996; as cited in Boden, 2012), conceptual art emphasizes on the idea that becomes the grammar for the work. As such, the traditional definitions of art are not exclusively independent. Each definition works within its complex interwoven parts—ontology, epistemology, and philosophy of mind, among others.

For Plato, the representational view that reveals the reality of a phenomenon is not an artistic work. Consequently, representational artistic practice, according to Plato, does not involve deep-seated thinking (as cited in Duncum, 2012). Beauty is not the distinctive preserve of the arts, according to Plato. However, Kant defines art as "a kind of representation that is purposive in itself and, though without an end, nevertheless promotes the cultivation of the mental powers for sociable communication” (Kant, 1952, section 44; Kant, 2000, section 44). One identifies elements such as formalist, representational, and expressivist elements in Kant's definition. These considerations on what counts as art or artistic practice still bring into focus the question of conceptual art.

Gaut (2000) contends that art is to be understood as a cluster concept and not in terms of a definition. In finding appropriate definition of art, we should "suggest ways of making sense of a practice which is not so uniform as to yield an essence of art and not so shot through with inconsistency as to resist any attempt at sense making” (Stecker, 2000, p. 61).

In the formative period of European culture, “art” in the words of Getlein (2002) was used synonymously with "craft" in the sense that they involve human practical skills. Activities such as weaving a fabric, reproducing of a carved stool and blacksmithing hoes were all considered art. Crafts were associated with mass produced art objects. Another school of thought is that the original art object based on which replicas are made is pure art. During the Renaissance period spanning from the fourteenth to the seventieth century, the heart of art was imitating nature, especially human figures, as closely as possible. That was the preoccupation of art at the time. There was a greater quest towards the search for realism fuelled by the spirit of revival and rediscovery of ancient Greco-Roman art (O’Sullivan, 1998) until the African-art-inspired twentieth-century Western art broadened the frontiers of what should be considered as art. Later, artists who created exact simulacrum of sitters and nature in general without peculiar personalized stylizations were considered as copy artists. The old tradition of 
commissioning artists to produce predetermined artistic concepts as in the case of many artists in the renaissance period also came under attack as impure art. Artists who fell under this category were tagged as commission artists.

The realization that written words are also images was anew to Western art in the 1900s (Getlein, 2002). Meanwhile many non-Western artistic cultures including Africa had developed and practised its writing system as art long ago. In Africa the writing system showing the use of glyphs are common to the Egyptians (Vansina, 1984), Mende (Sierra Leone), Loma (Liberia), Bamum (Cameroon), Nsibidi (Efik/Igbo) and Mum, Soma (Zambia and Angola), Gicandi (Gikuyu) and the Adinkra of the Akan (Ghana and Cote d'Ivoire) according to Biko (2011) as cited in Essel and Opoku-Mensah (2014). These writing systems were part of the art of the African peoples.

The assumptions about what art is or what it is not, historically, shaped the classification of certain art as fine art which primarily consisted of painting, sculpture, architecture, music and poetry; and music and dance as performing art in the eighteenth century. These branches of art were considered high art and enjoyed for their aesthetic reasons. Fisher (1993, p. 3) points out that "there are experimental twentieth-century artworks that lack that characteristic.” To consider only the aesthetic dimension of a work of art to classify it as art is complex issue since aesthetics concerns itself with the beauty and the ugly of a work of art. Many a time, the aesthetical tastes of art artworks are approached from the conceptual and contextual maneuvering in order to determine both the intrinsic and extrinsic characteristics of an artwork.

Massed produced objects—craft—-that had been considered "non-art" were reengaged in conceptual art as new form of art in the twentieth century, further deepening difficulty level involved in defining what constitutes art. From these scenarios, what constitute art is influenced by time, place, culture and history. Those artists who created artworks that were hailed at the time past as "great artworks" which in present times may be considered as craft do not lose their credentials as being great artists, neither could we discredit popular or folk art as art (Fisher, 1993).

\section{How African Art Has Been Perceived}

Available historical records point to the fact that African civilization had risen and fallen long before the rebirth of European civilization in the fifteenth century (Du Bois, Mahmood, \& Horne, 2007). However, the Western world made a preposterous and defamatory reference to everything African including her colour and cultural ideas as "dark”. Nkrumah (1964b, para. 4) gives a vivid account of the monstrous image portrayed about Africa. He made reference to a European author who wrote that "the history of civilization on the continent begins, as concerns its inhabitants, with Mohammedan invasion" and that African is poorer in recorded history than can be imagined. He further comments on similar statement documented in the 11th edition of Encyclopedia Britannica that:

Africa, with the exception of the lower Nile Valley and what is known as Roman Africa is, so far as its native inhabitants are concerned, a continent practically without history and possessing no records from which such history may be conducted ... the Negro (referring to the black man) is essentially the child of the moment and his memory, both tribal and individual, is very short, And if Ancient Egypt and Ethiopia be excluded, the story of Africa is largely a record of the doings of its Asiatic and European conquerors and colonizers. (as cited in Bomfeh, 2015, para. 8) 
Nkrumah admitted that it has taken a millennia and half of African history before the engagement in activities meant to set these misconstrued records straight. These misconceptions extrapolated from the above statement are that Africans have short retentive memory, no historical records, and have contributed nothing to world civilization. Yet Africa's artistic cultural ideas which were castigated as inferior were the potent force that sparked new directions in Western art traditions. African art were regarded as found art (Vansina, 1984). In our view, they were condemned as art composed of found art in the sense that the artists used a collection of "useless" natural or artificial materials (junks) to keep an artistic idea alive. That generic art of Africa showed its sensitivity towards the environment. Boiling with misjudgments, the Euro-Christian missionaries labeled African art with negatively despising descriptions such as primitive, pagan, fetishistic, child-like, superstitious and unscientific, just to mention a few, and still "relied on the creative expertise of the same African artists to promulgate its own Christian concepts in Africa” (Fosu, 1993, p. 4).

Artworks, in any society, are windows onto the cultural life of that society, and substantial indicators that foster a better understanding of the artistic ideas, expressions and philosophical concerns of the society. That is to say, artworks of the past African ancestry that was present long before their encounter with the colonialists should have served as the powerhouse of African artistic knowledge for the Westerners, if they had sought to understand the conceptual focus of the African artists. There is an Akan proverb which says "Se wo tamfo rusua wo asaw a, okyea ne paa" that translates as "If your adversary is making mockery of your dance s/he skews his/her waist." "The 'darkness' existed only in the minds of Western observers; it was an image of their own creation, fostered by their inability to appreciate African culture” (Dei-Anang, 1975, p. 195). Their successful practice of the slave trade for four centuries with intensive atrocities committed against the people of the continent might have caused these pronouncements against Africa. Even in the event of the slave trade in the seventeen century in Africa, the colonialists' contact did not "directly affect the art of most Africa to any great degree” (Vansina, 1984, p. 6).

To reinforce their own fabricated stale story of African art, the colonialists studied the works in a way to make it appear inferior to Western art. Conversely, the usage of the art should be dissociated from the appearance, and most importantly, the idea which is really the art should be considered. The art of any society was, traditionally, made to serve the needs of humans—be it physical, social, cultural, religious (Adams, 2002) and educational of which African art is no exception. To understand African art requires a thorough grasp of the Afrological colonnade of conceptual underpinning that supports her art. In the twentieth century, the avant-garde art movement in Paris developed an interest in sculptural forms from West and Central Africa and these were also noticed by art historians (Metropolitan Museum of Art, 2008). What was its appeal? Artists who were products of formal Western education described their perceptions of art based on formal qualities as distinct from those in their own cultural tradition. According to reports from The British Museum, "They read into them the kinds of symbolic meanings they were seeking to express in their own work, promoting the view that Africans could create art, but of a very particular kind” (British Museum Publications, 1981, p. 4 ). This was described by Jean Dubuffet in "Primitivism" in 20th Century Art as an affinity of the tribal with the modern (as cited in Museum of Modern Art, 1985). Frank Willet, a scholar of African art notes that "the greatest contribution Africa has made so far to the cultural heritage of mankind is its richly varied sculpture” (as cited in British Museum Publications, 1981, p. 10). However, the commodification of the arts reflects judgments on legitimacy as well as symbolic values that play a crucial part in the recognition of art objects as status symbols for individuals or public 
institutions. As a result, there is an extensive international business for the reproduction, exchange, and publication of such works. It is not surprising to find Africans creating art to satisfy international markets. The authenticity and symbolic value of such works known as "tourist art" that are mass-produced mainly for sale to Western buyers is difficult to ascertain.

\section{Nature of Conceptual Art}

The language of conceptual art could emanate from the perception of defining art as a form or shape or ideas given by one's imaginations using one's sensory experience and life of feeling within time and space. Conceptual art provides the artist with a sense of self, identity, pride, expression, and accomplishment that never goes away. Concepts are an individual's general ideas, thoughts and understanding, therefore conceptual art as a derivative of concept deals with works of art that are based on the artist's ideas. Gilbert (2002) defines conceptual art as “An art form in which the underlying idea or concept and the process by which it is achieved are more important than any tangible product” (p. 491). This implies that the process of expressing emotions in a work of art could be manifested through conceptual art making.

Conceptual art transcends traditional artistic practices as espoused by art critics and philosophers such as Danto, Dickie, Stecker, and Bell. Usually, it reflects something from the inner self, thoughts, or ideas that inform the design and production of artworks. Thus, any descriptive language used to explain it is not necessarily informed by the formalist, expressive, institutional or historical conceptions of art, but extends beyond these theories. For instance, from a broader perspective, The Concise Oxford Dictionary of Art Terms (2012) posits that conceptual art dates back to the primitive ${ }^{2}$ artists who included the skeletal framework of a fish in their cave drawings because they believe it was there, though not outwardly visible. Conceptual art attaches insurmountable interest to the idea used in the creation of an artwork without regard to the material, techniques and craftsmanship. The idea is rather the artwork in conceptual art. Making the idea as a prerogative, subdues interpretation of the art, and mellows the aesthetic pulsation of the artwork. It questions the traditional aesthetical clouds that surround the fine art (painting, sculpture, music, among others) thereby eliminating object-self-referential interpretation of that art. Conceptual art involves that kind of art that gives clueless information about the work itself to the observer and rather engages the mind to ask certain critical questions such as "Is this really art?", "How could this be art?" and "Does it fit into the conventional museum?" These raise the question of what should constitute an artwork, making further turnaround about the notion of art since conceptual art reengages crafts, photography, painting, ceramics, computer art, documentation —and junks, residing behind the idea portrayed. By and large, it increases the definitional complexity and focus of art in general. LeWitt (1966), as cited in Alberro and Stimson (1999, p. 11) argues that:

In conceptual art the idea of [or] concept is the most important aspect of the work. When an artist uses a conceptual form of art, it means that all of the planning and decisions are made beforehand and the execution is a perfunctory affair. The idea becomes a machine that makes the art.

Every artwork is driven by concepts, whether for functional, decorative or aesthetic reasons. Irrespective of the motivation or the paradigmatic sweep engineering the production of a particular art, planning and decision

\footnotetext{
${ }^{2}$ Primitive refers to the prehistoric period in artistic practice.
} 
beforehand are inherent, and not impossible to be swayed by accidental conceptual circumstance that may produce paradoxical effects. What LeWitt tries to put across, perhaps, is that when the execution, craftsmanship, and cultural associative strings are made perfunctory in conceptual art-making that the work is put at the service of the mind. Arriving at the idea derived from the concept becomes the main art while the media used and the execution becomes a mere formality not worthy of much concentration. As explained earlier, the intention is to derail the traditional notion of sensory perception that was at the heart of aesthetics.

LeWitt also puts forward in his essay "Sentences on Conceptual Art" that artists may use single or series of varying plans in giving basic forms or readily available forms to the idea in solving the problem. The form(s) is what he calls "grammar" for the entire artwork. Boden (2011, p. 75) regards conceptual art as some sort of "paradigm case of transformational creativity" since artworks that fall in that range of creativity is shocking, perhaps, unthinkable as art form or "anti-art" to be exhibited in a museum. The term "transformational creativity" as defined by Boden, involves the breaking of culturally sanctioned rules regarding the creation of artworks. He further suggested a litany of abstract instructions based on LeWitt's view on conceptual art that could be done in creating the artwork. Here, the artwork could be done by another person who would follow the instructions in getting the work executed. The artist could also fall on mass produced objects instead of handicrafts, conceptual interestingness instead of perceptible beauty, and other ideas that revolt against the conventional schema of art creation.

The 1960s witnessed a new generation of predominantly middle-class trained artists who began producing conceptual art, that rejected many of the premises of earlier modernism with the intention of making new shocking and difficult to accept kind of art, so as to satisfy their curiosity of reviving their perceived avant-garde artistic spirit. However, their approach was a reductivist aesthetic practice of using basic forms of perception that tend to close the gap between art and its public (Varnedoe, 1984). Their exploration was nothing less than the other twentieth century artists who used the so-called primitive art of Africa. Of all the Western artists including Robert Rauschenberg, John Cage, Lawrence Weiner, Joseph Kosuth, John Baldessari, Sol LeWitt, to mention but a few, that practiced the art since the 1900s, the French artist, Marcel Duchamp's first exhibition of a found object—urinal—as a work of art drew much attention of the artworld before and after his demise in 1968. Even some of his colleague-artists idolized him his as the father of conceptual art. Kosuth (1969), as cited in Alberro and Stimson (1999, p. 164) wrote in his essay titled “Art After Philosophy: Part 1" that "The 'value' of particular artists after Duchamp can be weighed according to how much they questioned the nature of art”. Art at the time had become seriously commercialized and commodified for their aesthetic, decorative, educative and functional reasons. Duchamp's attempt was to wean Western art from such materialization and cause spectators to disregard these traditional tastes of art and rather invest time in the concepts that begot the art. Meanwhile such material and conceptual exploration was in practice in African art. The early conceptual artists including Duchamp did not just borrow; they adapted the practice hook, line and sinker and named it conceptual art. Boden's (2011) argument that Duchamp's attempt was so much challenging the notion of art is highly contestable since that art practice was already in existence in Africa. That may be tantamount to reinventing the wheel.

\section{Conceptual Art: How Africans Lived It}

Having attempted to explore the basic constituents of conceptual art, one may be tempted to ask if 
precolonial art in Africa posed such artistic characteristics long before Islamic and colonialists' invasion. Is conceptual art really an emergent art in Africa? Is the idolization and adoration of Western artists as proponents of conceptual art justified? Is conceptual art a reinvention of African Art? These questions will continue to provoke academic debate that will eventually reshape the historicity of conceptual art in contemporary times.

Art in the African sense is a lived experience. It is the life-wire of both the physical and spiritual life of the African. Be it visual or performance art, the African approached it with unique conceptual strategy and powerful imagination irrespective of the purpose it served in the society. As a conceptual strategy, ancient African artists perceived nature as abstract configuration of forms in both visual and performance art in a way that the ideas conveyed by the forms or the performance matter the most. Fosu testifies that "African art is conceptual rather than representational. It is the ideas conveyed by the art forms which are crucial, rather than their mere visual representation" (1975, p. 34). With this strategy, the choice of media and the production process for the execution of artwork were arbitrary let alone it outward beauty. Once the idea behind a particular work is conveyed, the work is considered to be right, good or inwardly beautiful. The media and processes used became subservient to the accomplishment of the artistic idea. There is an Akan proverb which says What is right is what is beautiful. What is beautiful is what brings joy. What brings joy is what is goodness. This strategy sustained the conceptual eclecticism of African art that naturally showed total disregard towards realism and rather favoured abstractionism, conceptualism, nonconventional exploitation of found objects; and the development of cornucopia of motifs that serves ideational instruction. For instance in shrine art (see Figures 1 and 2) individual objects were not seen in isolation, they were arranged with radical artistic intent in a way that each object reinforced the composite sacerdotal assemblage. The arrangement has a conceptual duality: it may invoke panic or psychological tension, besides, the works did not rely on monetary considerations neither were the works subject to museum restrictions (Fosu, 1975; Getlein, 2002). They were created with conceptual freedom and their superficial arrangement in shrines showed disconnect in meaning making. The masked face with hairs glued to it (see Figure 3) would not be displayed alone in its typical African shrine art environment or home settings. It would be clad with assortment of found objects such as bones of animals, ivory, metal objects, fibres, leaves and strands of fabrics. Similar use of conceptual filter in objects placement, and media used is demonstrated in Figure 4 showing the reception room of the Igbo chief of Oguta, Nigeria. His heirloom consists of animal skulls and other bones, elephant tusks, fabric, animal skins, bells and imported mass produced materials. These collections were part of the everyday life of the people. Sensory perception of "beauty" is killed by the nature of objects and their arbitrary selection and arrangement. First time non-African observer of this assemblage may attempt to question "where" the art is, its aesthetic pulse and perhaps, meaning as in the case of colonialists prejudice thought about African art. Moving this assemblage of art objects to a different place or environment changes the arrangement. The idea portrayed is central to the extent that the materials used do not matter. Fosu (1975, p. 34) buttresses this point when he says:

... art in Africa is also lived; and this life is carefully structured to correspond to the shape of society, the invisible realities of which are made visible by art in order to reinforce existing social and moral values. For these reasons, traditional African art does not copy the ordinary. Instead art is accepted as a creative process that captures those essentials which give meaning to life. 


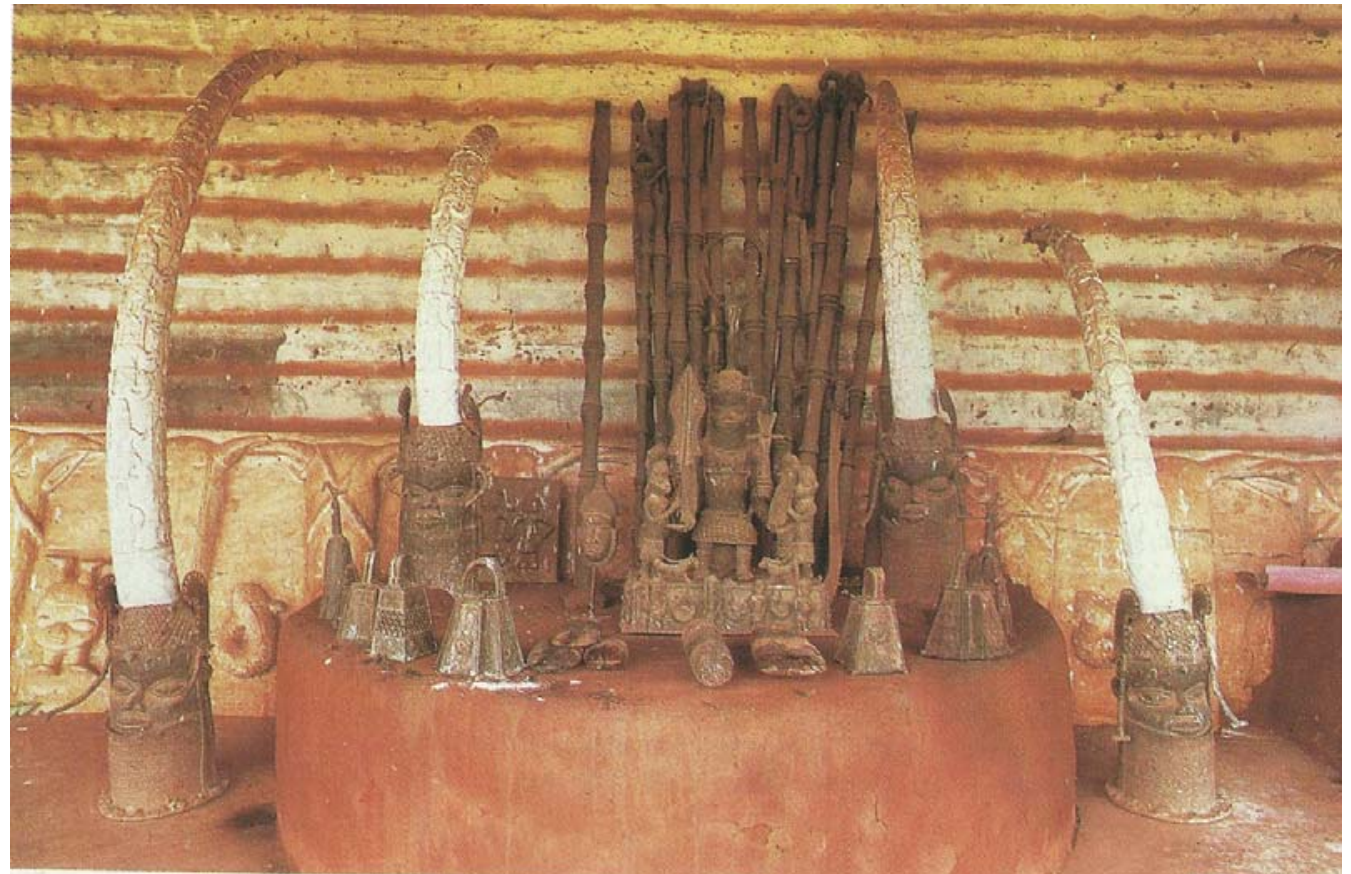

Figure 1. The palace altar to King Ovonramwen (r. 1888-97), Benin, Nigeria. (Source: Getlein, 2002)

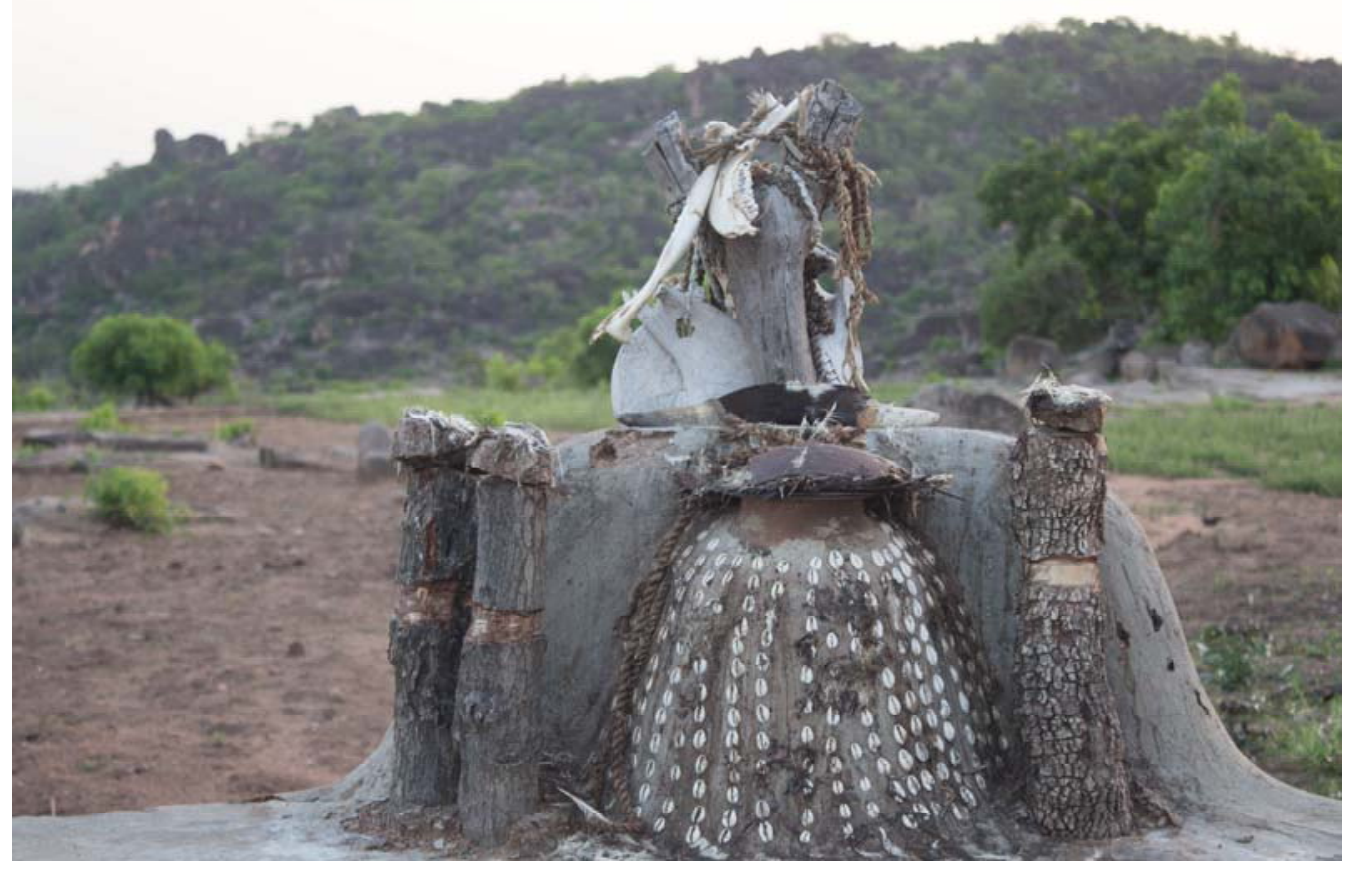

Figure 2. Part of Tongo Shrine. Ghana. (Photo Credit: Osuanyi Essel, 2016) 


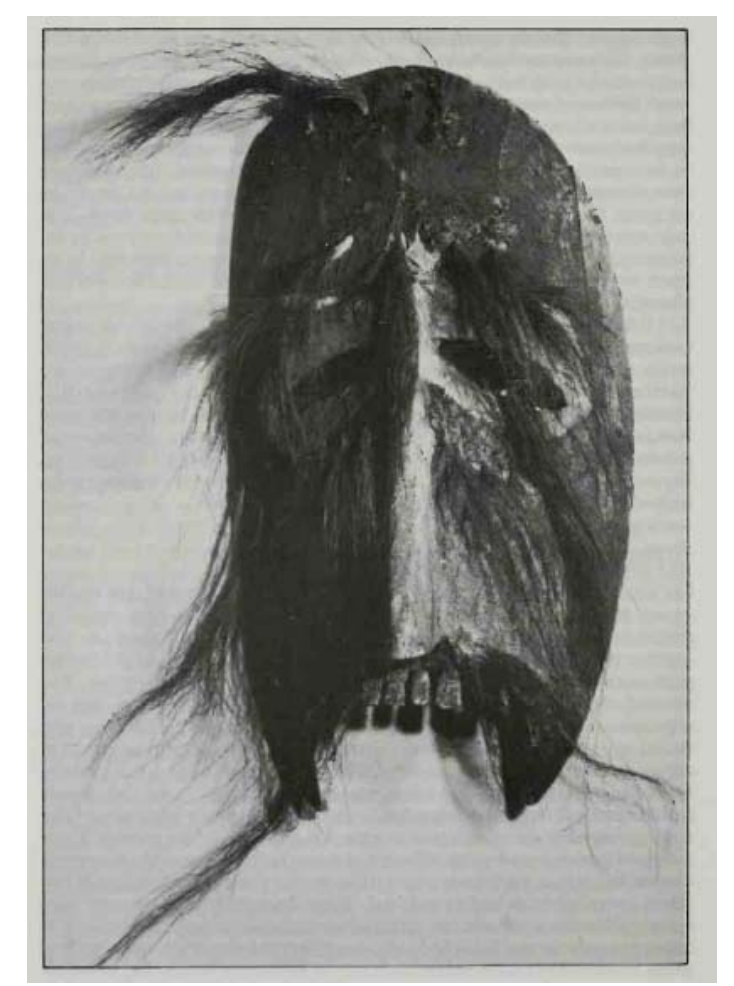

Figure 3. Carved wooden mask with hair attachment, eyes from bottle glass. (c. 1914) (Source: Vansina, 1984)

The use of mass produced handicraft objects and found objects with conceptual interest to create an art showed the philosophical cogency of ancient African artists. However, this was blacklisted and considered anti-art by the colonial invaders. In the twentieth century this very art which was branded as anti-art begun to feature in Western art and strangely hailed as "avant-garde".

Another example of conceptual instruction in African Art was epigraphic elements of African writing systems. These writing are composed of symbols just as any other writing systems in the world. They were developed with proverbial and idiomatic messaging that may eschew straightforwardness but imminent in brevity of expression (Essel \& Opoku-Mensah, 2014). Beyond their symbolisms, they served as source of instructional system in the creation of conceptual art. Ghana's adinkra and Nigeria's Nsibidi and Uli symbols are examples. Any of these symbols present thematic systemic instruction which when followed by perhaps, hundred artists may produce hundreds of artworks due to deferring interpretations that are invariably context specific. The observer becomes part of the interpretation. John Baldessari's Pure Beauty, 1966-68 (see Figure 5); Everything is Purged From This Painting But Art, 1966 (see Figure 6); Joseph Kosuth's One and Three Chairs,1965 (see Figure 7) and One and Five (Clock), 1965 (see Figure 8) tow that line. 


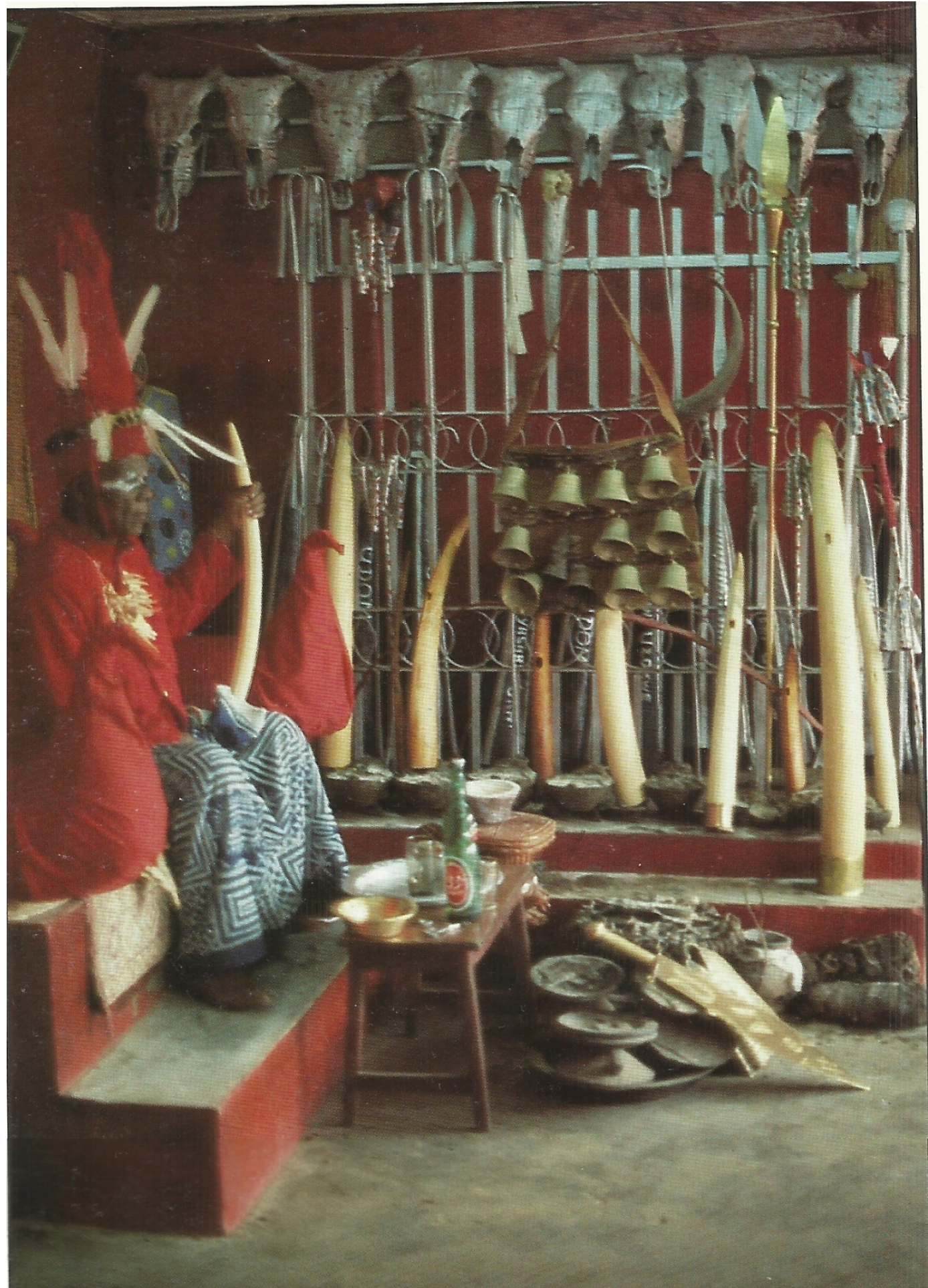

Figure 4. Reception room of Oguta, Igbo chief, mix heirloom ritual objects arrangement. Nigeria. (Source: Cole, 1989). 


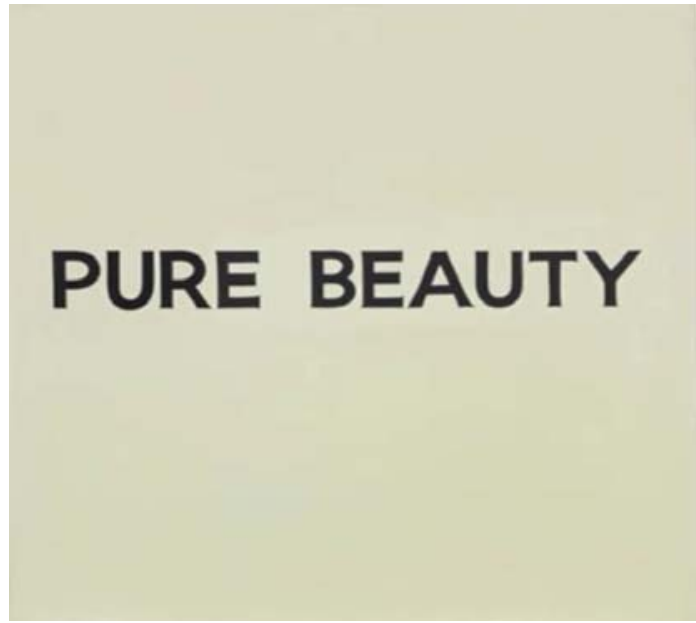

Figure 5. John Baldessari. Pure Beauty, 1966-68.

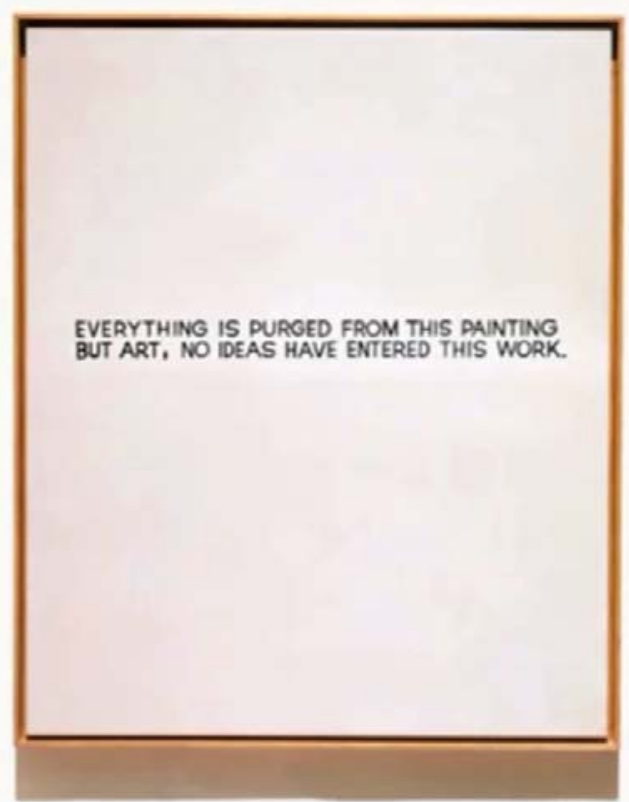

Figure 6. John Baldessari. Everything is Purged From This Painting But Art, 1966. 1966-68.

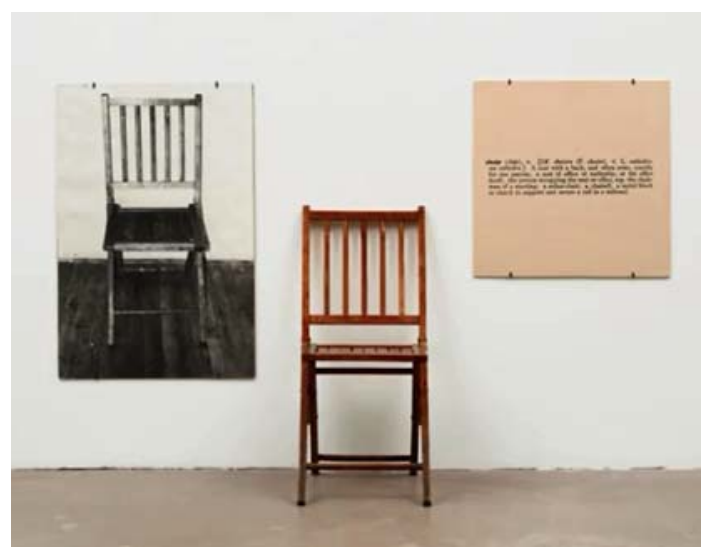

Figure 7. Joseph Kosuth. One and Three Chairs, 1965. 


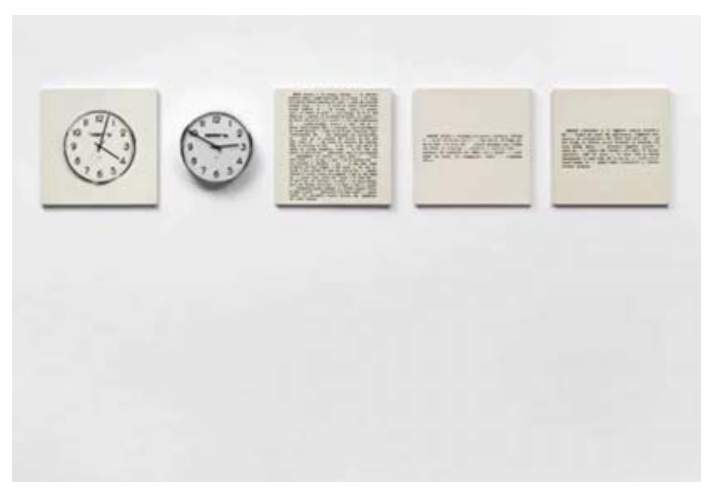

Figure 8. Joseph Kosuth. One and Five (Clock), 1965.

One of the interesting aspects of Africa is her performance art. The life of the ancient Africa was performative. Most of her visual artworks including masks, pots, fabrics, beads, carved or modeled figures, were used in performance art. Her performative art positioned both the observed and the observer in a two way traffic - counter-observation. The performances were not separated from the observer, for it was not performed on stage. Examples are masquerade performance during installation of warrior chiefs among the Bamum of Cameroon (see Figure 9) and agricultural activities as in the case of the Bambara of Mali and other performances in the societies meant for educational and entertaining contexts. Typifying masquerades costume was the use of assorted found objects, grass, raffia and others which also not considered as "noble” materials for art-making. Ancient African maskers performed visual drama whose conceptual power has been relegated to the background. The costuming and the performance may carry iconographic reference but the most importantly the idea fuelling the performance is the epicentre of the celebration and the art itself. The ideas portrayed in this art (see Figure 9) send the observer to the wonderland in search for whether or not it qualified to be named as art.

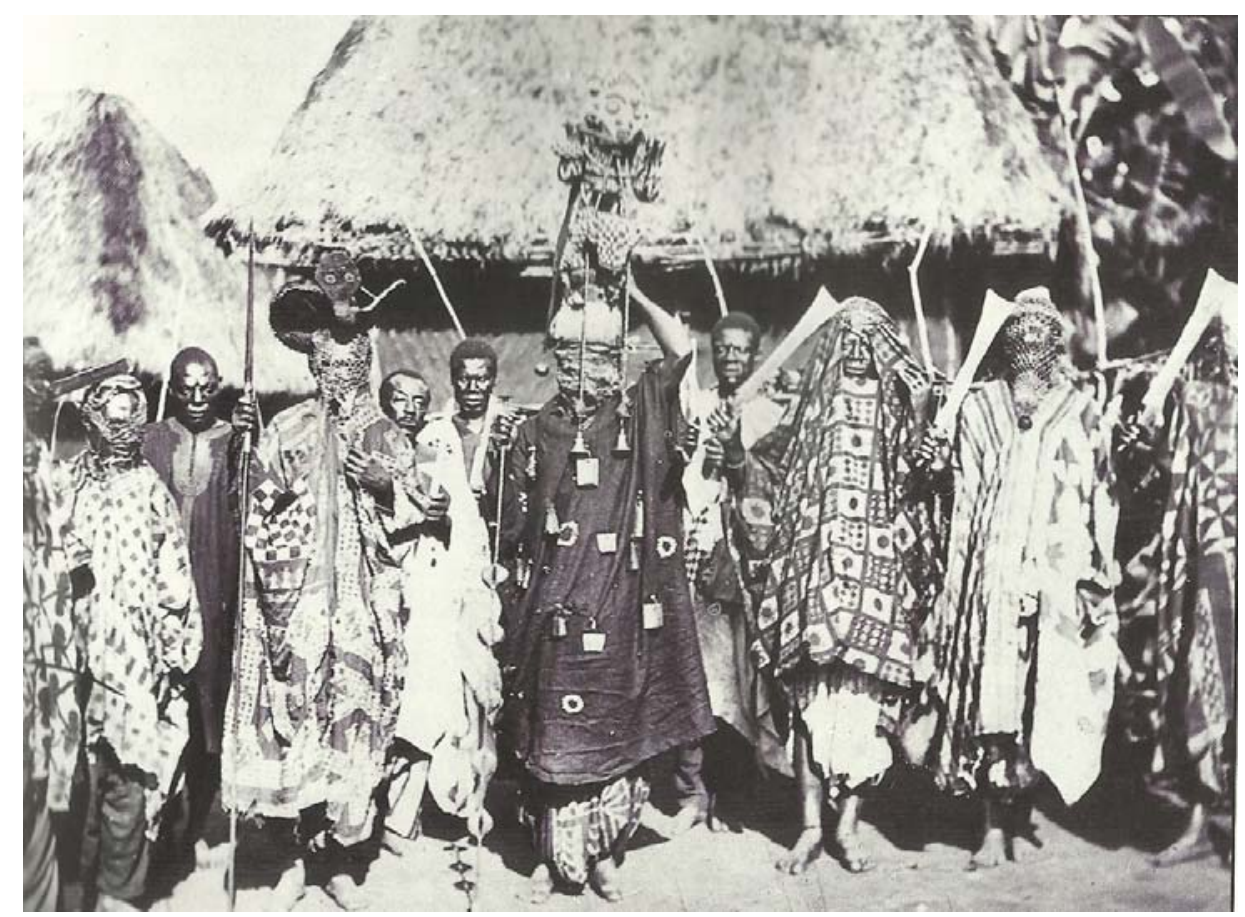

Figure 9. Installation of Bamum war chief (fifth from left) costumed in imposing headdress. c.1912. (Source: Cole, 1989). 


\section{Conceptual Art: Beyond the Functionality and Symbolisms}

As already established, art means almost everything to the African. It is manifested in every aspect of their lives including their arts. In visual art, because perishable materials were used in the making of art, much of the historicity surrounding them has gone down the drain. The remnants of Africa's art tradition which has been researched into shows her artistic prowess. "More than any other artistic tradition, the arts of Africa challenge us to expand our ideas about art, what art is, what forms it can take, what impulses it springs from, and what purposes it serves” (Getlein, 2002, p. 435). Nonetheless, much of the existing researches in African Art focused on its functionality, symbolisms, communicativeness, psychological, religio-political and its aesthetical considerations. African arts were invariably portrayed as art/object of meaning making. Even the scholarly aesthetical concerns about her art were viewed with Eurocentric aesthetic canon of formalistic conventions that paid no attention to Afrological aesthetics which deals with the conceptual and contextual lenses of her art. This provided the ammunition for the negative labeling of Africa's art since it did deviate from the Eurocentric artistic canon of what should be termed as art.

What little is known about is that ancient Africans practiced what is known today as conceptual art centuries before and after their encounter with the colonialists. The artistic complexity of her art pulls the strings of meaning making such as functionality, iconography and religiosity together and seemingly blurs its conceptual focus. But be it performance or visual art, these meaning making attributes might be interwoven with its usually conceptual traits. Whether these attributes were interwoven or not, the idea expressed by the produced work reigns supreme. It is the scholarly deficit, on the part of Africa, to this aspect of her art that has created the vacuum. However, there are traces of her art in conceptual art practice of the artworld that validates this argument. Perhaps, the voices of the conceptual practitioners of art in Africa or non-Western form of art did not receive public scholarly recognition years before the concepts' association to artists such as Marcel Duchamp, Robert Rauschenberg, Joseph Kosuth, and their contemporaries. This is evident in little attention given to the traditional arts of Africa in publications within the Western world, centuries ago (Enwezor, 2016).

However, there have been some publications on African arts. A catalogue on Ghana: Yesterday and Today by Owusu-Sarpong (2003) highlights traditional arts of Ghana's art and its correlation to contemporary and popular art. Also, some other catalogues and journal articles address Ghanaian contemporary art in a modern world (Fosu, 2004; Fosu, 2009). In spite of scholarly publications on African art by scholars such as Kojo Fosu, Atta Kwami, Akwasi Sarpong, Emmanuel Asihene, Labi, Quarcoopome, Anquandah, among others, Araeen (2005) shows concern about inadequate scholarly writings in art by Africans and therefore calls on Africans to step up their participation. Perhaps, this situation partly account for the apparent silence of conceptual art in Africa before the advent of the mid-twentieth century. Labi (2013) bemoans this problem exists not only in Ghana but in other African countries such as Kenya and Uganda.

For Pereira (2016), conceptual art was a movement that was probably the most radical and contentious plane in modern art $^{3}$. Conceptual art is based on the notion that the essence of art is an idea, and may exist distinct from representation. Since ideas are the main feature of art, material concerns have a secondary role in conceptual art. For Pereira, conceptual artists recognize that all art is essentially conceptual. In order to contextualize the term,

\footnotetext{
${ }^{3}$ Modern art here refers to the 20th century art.
} 
they limit the material presence of the work to an absolute minimum. This is what Pereira considered as the dematerialization of art-that is one of the main features of conceptual art.

Kolbowski (2000) also observes a rising interest in conceptual art across the globe at the beginning of the twentieth century and felt that there was an inadequate history of conceptual art. Kolbowski was motivated to undertake a project that sought to raise some questions about the return of conceptual art. He believes that if he interviews artists to speak from memory about conceptual project from the past, the findings would include significant memoirs and misconceptions of human memory. Commenting on African conceptualism, Enwezor (2016) observes that the term conceptual art has been institutionalized and narrowed in scope with emphasis on “artistic discourses of postwar Western Europe and the United States" (para. 1). This attests to the issue of prevailing silence of African aesthetic concept from a wider discourse of modernism. The following questions were further raised by Enwezor (2016):

Would conceptualism in Africa, like its Euro-North American counterpart, constitute a significant shift within the dominant institutional framework as to posit a new language or paradigm? If so, what specific labels were applied to this shift, how were they received and discussed? Do these labels constitute a movement in which many artists participated? Quite simply, is there such a thing as conceptual art in Africa, or is it just a term imported as part of a neocolonial enterprise of modernist art history? (para. 2)

The foregoing discourse implies that conceptual art was practiced in Africa long before the advent of the twentieth century. This notion of conceptualism aligns with the basic philosophical questions of African systems of meaning as in traditional African art. Though many African sub-cultures produced exquisite objects centuries ago, many of which influenced Western modernists to explore diverse forms of representation in art, it should be noted that African artifacts were conceptual. Sometimes, the aesthetic real of African traditional art are projected through nonvisual codes and performances. In a critique of conceptual art, Leuthold (1999) argues that conceptual art is a movement that did not lead to the development of a clearly defined philosophy of art that might be called conceptualism. Leuthold rather linked it with the goals of the avant-garde; considering it as a historical occurrence rather than a fully developed philosophy of art.

\section{Conclusion}

Conceptual art had been in active practice for centuries in African art long before it was seemingly reinvented in Western art in the twentieth century. The art was not originally named conceptual art by its African originators. To the African, the art was a lived experience and manifested in their everyday art. It took both performative and visual form. Found object and varied junk materials used to keep an artistic idea alive were censured in the eyes of the many Western observers though this generic art of Africa showed sensitivity towards the environment.

There exist huge scholarly deficit on the conceptual art of Africa. This gave some of the early Western critics, who began to write on African art skewed self-glorifying interest and studied European influence on African art and kept silent on how the arts of Africa brought renewed interest in the twentieth century art. They limited the study of African art to its symbolic nature, everyday functionality, religio-magical and socio-political dimensions to paint a grotesque and mundane perceptual imagery of African art. As a result, it was tagged as “primitive art”. But ironically, this art inspired the 20th century art movements. Pablo Picasso, Henry Moore and 
other Western artists have publicly registered their allegiance to the African arts. The arbitrary use of colours, conceptual ideas and abstraction that appeared in Western art are confirmed legacies of African art.

Conceptual art takes its roots from Africa and therefore not an emerging art in the African experience as it is perceived. The adoration and idolization of Marcel Duchamp as the father of conceptual art is also contestable since the art was many centuries old in Africa before he began to practice it in the West. Duchamp's attempt at dematerialization of art and conceptual exploration was in practice in African art. Duchamp and his contemporaries adapted the conceptual art of Africa hook, line and sinker.

\section{References}

Adajian, T. (2012, October 9). The definition of art. In N. Z. Edward (Ed.), The Stanford encyclopedia of philosophy. Retrieved from http://plato.stanford.edu/archives/win2012/entries/art-definition/

Adams, L. S. (2002). Art across time. New York, NY: McGraw-Hill Companies Inc.

Alberro, A., \& Stimson, B. (Eds.). (1999). Conceptual art: A critical anthology. Massachusetts: Massachusetts Institute of Technology.

Amenuke, S. K., Dogbe, B. K., Asare, F. D. K., Ayiku, R. K., \& Baffoe, A. (1991). General knowledge in art for senior secondary schools. London: Evans Brothers Ltd.

Antubam, K. (1963). Ghana's heritage of culture. Leipzag: Koehler \& Amelang.

Araeen, R. (2005). Modernity, modernism, and Africa's place in the history of art of our age. Third Text, 19(4), 417.

Biko, F. (2011, March). Religion Africa's gift to the world. Africa Watch, 56-62.

Boden, M. A. (2011). Creativity and art. New York, NY: Oxford University Press.

Boden, M. A. (2012). Creativity and art: Three roads to surprise. Oxford: Oxford University Press.

Bomfeh, J. K. (2015, May 29). Ghana's politics on insincerity. Retrieved July $12, \quad 2016$ from http://www.ghanaweb.com/GhanaHomePage/NewsArchive/Ghana-s-Politics-of-Insincerity-359763

Carroll, N. (2002). Philosophy of art: A contemporary definition. New York: Routledge.

Carroll, N. (Ed.). (2000). Theories of art today. Madison: University of Wisconsin Press.

Chisholm, H. (Ed.) (2016). “African Tribal Distribution”. In 1911 Encyclopedia Britannica (11th ed.). Retrieved July 12, 2016 from http://www.studylight.org/encyclopedias/bri/view.cgi?n=640

Cole, H. M. (1989). Icons: Ideals and power in the art of Africa. Washington, D.C.: National Museum of African Art.

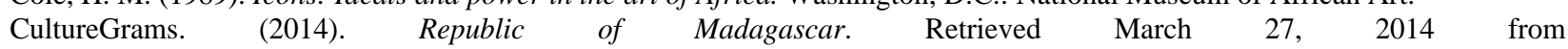
http://www.culturegrams.com/images/samples/Madagascar2014.pdf

Danto, A. (1981). The transfiguration of the commonplace. Cambridge: Harvard University Press.

Davies, S. (1991). Definitions of art. Ithaca: Cornell University Press.

Davies, S. (2004). The cluster theory of art. British Journal of Aesthetics, 44(3), 297-300.

Davies, S. (2006). The philosophy of art. Oxford: Basil Blackwell.

Dei-Anang, M. (1975). History of the black peoples of Africa. In World encyclopedia of black peoples (Vol. 1, pp. 194-219). Michigan: Scholarly Press, Inc.

Du Bois, W. E. B., Mahmood, M., \& Horne, G. (2007). The world and Africa and color and democracy. Oxford: Oxford University Press.

Duncum, P. (2012). Popular aesthetics. Lecture Notes. Champaign: University of Illinois at Urbana-Champaign.

Enwezor, O. (2016, March 20). Where, what, who, when: A few notes on “African” conceptualism. Retrieved July 12, 2016 from http://www.artafrica.info/html/artigotrimestre/3/artigo3_i.php

Essel, O. Q., \& Opoku-Mensah, I. (2014). Pan-African artistic reflections in Kwame Nkrumah Memorial Park. International Journal of African Society Cultures and Traditions, 1(2), 30-41.

Fisher, J. A. (1993). Reflecting on art. California: Mayfield Publishing Company.

Fosu, K. (1975). Art and sculpture of the black peoples of Africa. In World encyclopedia of black peoples (Vol. 1, pp. 33-44). Michigan: Scholarly Press, Inc.

Fosu, K. (1993). 20th century art of Africa. Accra: Artists Alliance Gallery.

Fosu, K. (2004). Contemporary art in Ghana, transitions: Samtidskunst Fra Ghana. Copenhagan: Ulandssekreariantet.

Fosu, K. (2009). Pioneers of contemporary Ghanaian art. Accra: Type Company Ltd.

Gaut, B. (2000). “Art” as cluster of concepts. In N. Carroll (Ed.), Theories of art today (pp. 25-44). Wisconsin: The University of Wisconsin Press.

Getlein, M. (2002). Gilbert's living with art (6th ed.). New York, NY: McGraw-Hill.

Kant, I. (1952). The Critique of judgment. Oxford, UK: Clarendon Press.

Kant, I. (2000). Critique of the power of judgment. (P. Guyer \& E. Matthews, Trans.). Cambridge: Cambridge University Press.

Kolbowski, K. (2000). An inadequate history of conceptual Art, 92, 52-70.

Labi, K. A. (2013). Art studies in Kenya. Third Text Africa, 3(1), 99-101. 
Leuthold, S. (1999). Conceptual art, conceptualism, and aesthetic education. Journal of Aesthetic Education, 33(1), 37-47.

Lewitt, S. (1996). Paragraphs on conceptual art. In K. Stiles and P. H. Selz, Theories and documents of contemporary art. Berkeley: University of California Press.

Metropolitan Museum of Art. (2008). African influences in modern art. Retrieved March 27, 2016 from https://www.metmuseum.org/toah/hd/aima/hd_aima.htm

Museum of Modern Art. (1985). "Primitivism" in 20th century art: Affinity of the tribal and the modern [Press release]. Retrieved from https://www.moma.org/momaorg/shared/pdfs/docs/press_archives/6081/releases/MOMA_1984_0017_17.pdf?2010

Nkrumah, K. (1963). The African genius (Speech by Osagyefo Dr. Kwame Nkrumah, President of the Republic of Ghana, at the opening of the Institute of African Studies on 25th October 1963).

Nkrumah, K. (1964a). Consciencism. London: Panaf Books Ltd.

Nkrumah, K. (1964b). Dr Kwame Nkrumah (Speech by Osagyefo Dr. Kwame Nkrumah, President of the Republic of Ghana, At the Opening Session of the First Meeting of the Editorial Board of the Encyclopedia Africana on Thursday, September 24, 1963 at the University of Ghana). Retrieved 08/09/2015 from http://www.papelesdesociedad.info/IMG/pdf/dr_kwame_nkrumah.pdf

O’Sullivan, A. (1998). Appreciation and history of art. Dublin: Gill \& Macmillan Ltd.

Owusu-Sarpong, C. (2003). From words to ritual objects. In C. Owusu-Sarpong and C. Falgayrettes-Leveau (Eds.), Ghana: Yesterday and today. Paris: Museé Dapper.

Oxford Reference. (2012). Definition of art. In The concise Oxford dictionary of art terms (2nd. Ed.). Retrieved July 12, 2016 from http://www.oxfordreference.com/view/10.1093/acref/9780199569922.001.0001/acref-9780199569922

Pereria, L. (2016, March 20). Conceptual art movement and examples. Retrieved from http://www.widewalls.ch/conceptual-art-movement-and-conceptual-art-examples/

Rubin, W. (1984). "Primitivism” in 20th century art. New York, NY: The Museum of Modern Art.

Stanford Encyclopedia of Philosophy. (2012). The definition of art. Retrieved July 12, 2016 from http://plato.stanford.edu/entries/art-definition/

Stecker, R. (1996). Definition of art. In J. Levinson (Ed.), Oxford Handbook of Aesthetics (pp. 136-154). Oxford: Oxford University Press.

Stecker, R. (2000). Is it reasonable to attempt to define Art? In N. Carroll (Ed.), Theories of art today (pp. 45-64). Wisconsin: The University of Wisconsin Press.

Stecker, R. (2005). Aesthetics and the philosophy of art. Lanham, MD: Rowman and Littlefield.

British Museum Publications. (1981). What is African art? Retrieved March 27, 2016 from https://www.britishmuseum.org/PDF/british_museum_african_art.pdf

Vansina, J. (1984). Art history in Africa. New York, NY: Longman Group Limited.

Varnedoe, K. (1984). Contemporary explorations. In W. Rubin (Ed.), “Primitivism” in 20th century art (pp. 661-685). New York, NY: The Museum of Modern Art.

Vogel, S. (1990). Forword. In Close up: Lessons in the art of seeing African sculpture. New York, NY: Center for African Art. 